\title{
Examination of Children's Playing Game Tendencies and Digital Game Preferences Based on Gender
}

\author{
Ekrem BAHÇEKAPILI ${ }^{1} \quad$ Merve YILDIZ $^{2} \quad$ Erhan ÇİFTCİ $^{3} \quad{\text { Hasan } \text { KARAL }^{4}}^{4}$
}

Gönderim Tarihi: 21.02.2022

Kabul Tarihi: 04.03 .2022

Yayın Tarihi: 19.04.2022

\begin{abstract}
This study reports on a survey of 4-8th grade students' ( $\mathrm{N}=10139)$ playing game tendencies and digital game preferences based on gender. Descriptive statistics were used to determine the children's playing game tendencies and digital game preferences. And also, frequent pattern mining was used to discover which digital games are played frequently and together by children. The findings showed that children have an increased time spent playing games on weekends and boys tend to playing game more than girls. On the other hand, action games stood out as the most common choice among the children both girls and boys. In terms of game language, Turkish and English games were preferred almost equally. In addition, children mostly preferred digital games that can be played online, offering in-app purchases, and played on mobile devices. According to the frequency of playing, it was found that the children mostly preferred to play Minecraft, followed by Subway Surfers and Hay Day, respectively. In terms of gender, it was concluded that girls mostly preferred Subway Surfers, while boys played Hay Day. When the games were considered according to the frequency of playing together, Temple Run and Subway Surfers games among girls, and FIFA and Piano Tiles games among boys can be played together. The research reveals more detailed information about children's game preferences in terms of gender.
\end{abstract}

Keywords: Playing game tendency, Digital game preference, Gender, Children, Frequent pattern mining

\section{INTRODUCTION}

Games, which have an important role in the development of culture and civilization, are as old as human history. Huizinga (1955) defines the concept of play as one of the purest physical and biological activities of human beings, which have existed before, and which guide the way for culture. Games essentially represent worlds enabling distinct reflections of the real perceptions involved in culture (Doğu, 2006). Playing game is an action that has an important function in providing the competencies that animals and humans can demand from them in early developmental stages (Sutton-Smith, 2004a). Despite many studies on games, researchers have yet to come up with a consensus regarding the definition of the game and its common structural components (Colman, 2016; And, 2003). According to dictionaries game is defined as "activity for entertainment" (Oxford English Dictionary) and "entertainment that develops talent and intelligence, has certain rules, and helps to have a good time" (TDK).

With the effect of technological developments, the understanding of entertainment has changed and traditional games have gained a digital dimension, leaving their place to games in virtual environments. When it comes to the digital game environment, it is very difficult to distinguish the terms computer, internet, and game from each other. Kirriemuir (2002) stated that the terms "digital video games" and "computer games" can often be used interchangeably. In the literature, digital games can also be called by various names such as video games, virtual games, console games, computer games, electronic games (Eni, 2017).

\footnotetext{
${ }^{1}$ Karadeniz Teknik Üniversitesi, Türkiye, ekrem61@gmail.com, ORCID: 0000-0002-7538-1712

2 Karadeniz Teknik Üniversitesi, Türkiye, mrvyildiz.86@gmail.com, ORCID: 0000-0002-8665-0287

3 Trabzon Üniversitesi, Türkiye, erhanciftci81@gmail.com , ORCID: 0000-0002-9716-4399

4 Trabzon Üniversitesi, Türkiye, hasankaral@trabzon.edu.tr, ORCID: 0000-0002-3555-050X
} 
In this direction, Çetin (2013) defines digital games as games that are programmed with various technologies and offer a visual environment with user input. On the other hand, Yiğit (2017) refers to digital games as the games played on several devices such as computers, smartphones, game consoles, tablets, etc.

In the literature, it is possible to come across a wide variety of classifications of digital games. One of the first classifications of games was developed by the French gaming sociologist Roger Caillois. Caillois (1961) analyzed games through a lens based on four categories: competitive, chance, simulation, and vertigo games. Competitive games involve several game types such as football, tennis, golf, boxing, or chess, which are based on individual or group competition. Games of chance refer to a wide range of games such as roulette, dice games, or lottery. Simulation games are based on the player's assumption of the role of another person, object, or animal, simulating the latter's acts. Role-playing games are often included in this category. Vertigo games, on the other hand, are the ones that can lead to distinctive fluctuations in human perception, causing dizziness, loss of direction, and disconnection from one's actual physical environment. Games based on virtual reality goggles are usually examples of this category (Sezgin, 2016). Yet another study categorized games again in a four-fold structure, like card games, athletic games, child games, and computer games (Crawford, 1984). When computer games began to be defined as a different category, the game theorist Sutton-Smith (2004b) developed a sub-categorization of digital games, including logic games, individual games, acts based on game-like behaviour, performance-based games, informal social games, games of simulation, celebrations, and festivals. In another study, in turn, Kukul (2013), states that digital games can classify in a variety of forms based on the purpose of the game, the form of gameplay, the number of players, and the environment it is played in.

Individuals often refer to taking a rest, lack of alternative activities, spending some free time, having fun, relaxing, competitive motivation, challenges presented, relieving stress, developing one's intelligence, providing means for socialization, and avoiding the pressures of real-life as their justification and motives for playing digital games (Griffiths \& Hunt, 1995; İnal \& Çağ1ltay, 2005; Kirriemuir, 2002; Tüzün, 2004; Wan \& Chiou, 2006). The studies so far reveal that playing digital games is one of the most common activities children in primary school age develops a habit out of. In this context, the literature notes that digital games support the imagination of children, help develop hand and eye coordination, pave the way for scientific thinking based on mathematics and basic sciences such as physics, and contribute to socio-cultural, mental, psychological, and biological development of children (Horzum, 2011; Horzum, Ayaş \& Balta, 2008; Yang, 2012; Yiğit, 2017). On the other hand, some studies argue that digital games are not as harmless as they are claimed to be, that these games affect the physical, mental and academic development of children negatively, and that they bring along a very important problem such as addiction (Hawi, Samaha \& Griffiths 2019; Horzum, 2011; Torun, Akçay \& Çoklar, 2015). In addition to the studies investigating the effects of digital games, what these games are, their features, and the reasons for their preference are also some of the focal points of research on digital games.

The literature points at a significant increase in the time children spend playing computer games in the last 30 years and note that, on average, primary and secondary school students spend 4 to 13 hours per week on digital games (Uluyol, Demiralay, Şahin \& Eryllmaz, 2014). In a study with Finnish students, Männikkö et al. (2018) noted that respectively 43\%, 24.5\%, and $32.5 \%$ of 7 th, 8 th, and 9th graders play digital games. In another study carried out with students in the 11-16 age group, de Leeuw, de Bruijn, de Weert-van Oene and Schrijvers (2010) found that $72.5 \%$ of the 
students play digital games, whereas the average time spent in games in a week was 3.24 hours. Similar findings were reached in a survey carried out by Pew Research Center in 2014-2015, with 1050 teenagers in the 13-17 age group, revealing that $72 \%$ of children play digital games (Lenhart, Smith, Anderson, Duggan \& Perrin, 2015). Working with 5th and 6th grade students, Oflu and Yalçın (2019) found that, during weekdays, $77.6 \%$ of the students involved in the study played games less than 2 hours per day, 15.9\% played 2 to 4 hours per day, and \%6.5 played more than 4 hours per day. The figures for weekends are $46.9 \%$ for less than 2 hours, $36.7 \%$ for $2-4$ hours, and $16.3 \%$ for 4 hours or more. In terms of gender differences, compared to girls, boys were observed to spend more time on digital games (Hastings, Karas, Winsler, Way, Madigan \& Tyler, 2009; Männikkö et al., 2018). Concerning digital game genres, on the other hand, the children were usually found to prefer action-adventure games (Oflu \& Yalçın, 2019; Thorne, Smith, Morgan, Babic \& Lubans, 2014).

Phan, Jardina, and Hoyle (2012) found that boys prefer violent games and girls prefer socially based games in their research on digital game playing and gender preferences. According to the results of the same research, boys tend to play games in strategy, role-playing, action, and fighting games, while girls tend to play games in sociality, puzzle/card, music/dance, education, and sports. Yee (2006), in his research with 6675 gamers who play multiplayer online role-playing games, found the factors that define the motivations of players to play online games, grouping these factors under the categories of success, sociability, and addiction, and investigated the differences by gender. Accordingly, boys preferred games that focus on success and winning, while girls preferred games that require sociability and interaction. Quaiser-Pohl, Geiser and Lehmann (2006) conducted a study with 861 high school students using the method of hidden class analysis, and their children were divided into groups regardless of their gender. According to the results of the research, the group with most of the girls ( $83 \%$ girls, $17 \%$ boys) preferred to play logic and skill games, while the group with most of the boys ( $82 \%$ boys, $18 \%$ girls) preferred action and simulation games. Kinzie and Joseph (2008) found that in their research on the digital game preferences of middle school students, boys prefer active strategy and girls prefer creative and exploratory games.

This study aims to better understand the gaming patterns of children, both girls and boys, through a large-scale survey that asks questions about playing game tendencies and digital game preferences. Gender is a fundamental characteristic that underlies the behaviour and societal roles of men and women (Veltri, Krasnova, Baumann \& Kalayamthanam, 2014). Therefore, it can be said that it is important to define the differences between them. Because these differences are likely to transfer to playing game habits or reflect in game preferences, this situation will be valuable for game developers, education professionals, and researchers. In this context, it is thought that this study will contribute to the understanding of the current situation in different research areas such as education, psychology, informatics, which may depend on children's digital game playing habits. This objective, the following questions were investigated in the study by gender:

- What are the children's playing game tendencies?

- What are the children's digital game preferences?

- Which digital games are popular and played together among the children? 


\section{METHOD}

The study is based on the survey research, which represents a nonexperimental research design of quantitative research method (McMillan \& Schumacher, 2010) to determine playing game tendencies and digital game preferences of children.

\section{Participants}

The study design was adopted using a survey of the population of 4-8th graders from 420 public schools, which are in Trabzon, Turkey $(\mathrm{N}=40500)$. The survey forms were delivered to all schools through the Provincial National Education Directorate. However, some data were excluded due to the problem of being answered, and the analyses were carried out on a sample of 10139 students. The study group consists of 4398 girls (\%43.38) and 5741 boys (\%56.62).

\section{Data Collection Tool}

The survey form was developed in three stages. The first stage involved the preparation of a draft survey form based on a review of the literature on this topic, and its application with 50 students enrolled in 4-5th grades. Thereafter, in the light of the data derived through the initial application, the survey form was revised in consultation with two Turkish language experts in terms of language and meaning, and with five computer and education and instructional technologies experts in terms of formal structure and alignment with the purpose. Then came the second stage, where the revised survey form was applied on a pilot-study basis, with 1562 students enrolled in 5-8th grades. In the third stage, the data derived from the second stage were consulted with the same experts again, necessary revisions were made and the survey was given its final form.

The survey form contains questions about: (1) the gender of the student (girl or boy), (2) time spent playing games on weekdays and weekends (none, half an hour, 1 hour, 2 hours, 3 hours, 4 hours or more and don't know), (3) way of game play (non-digital games, computer games, smartphonetablet and game console) and (4) whether the student plays a specific game (62 specific games' name and other choices).

Based on the special digital game names, 5 game features were re-coded. These are (1) game genre (action, adventure, classic, puzzle, racing, simulation, sports, and strategy), (2) game language (Turkish and English), (3) payment options (paid, free and in-app purchases,), (4) online/offline options (online, offline and online/offline), and (5) game platform (mobile, pc, console, PC/mobile, $\mathrm{PC} /$ console and $\mathrm{PC} / \mathrm{mobile} /$ console). While calculating the value of each feature of the game for the student, it was checked whether there was a related feature in the games played by the student. If at least 1 game has this feature, it is coded as playing the game for this student. For example, if any of the games played by the students is a strategy genre, the strategy variable is coded as "playing", otherwise "not playing" for this student.

\section{Data Analysis}

As for the analysis of the data, different statistical were used in line with the research questions. Within the scope of the first two research questions, descriptive statistics (frequency, percentage) were used to determine the students' playing game tendencies and digital game preferences. In the last research question, frequent pattern mining was used to discover which digital games are played frequently and together by students.

Association rules generated with frequent pattern mining are the discovery of interesting associations and correlations between item sets in transactional and relational databases (Han, 
Kamber \& Pei, 2011). Jia (2009) explains association rules as follows:

“...the item sets $I=\{i 1, i 2, \ldots$, in $\}$ is the set which includes $n$ different items. Given a transaction database $D$, each transaction record in it is a subset of the sets $I$. The association rule is described as $X \Rightarrow Y$, here $X \subset I$, $Y \subset I$ and $X \cap Y \neq \Phi . "$

Usually support, confidence and correlation metrics are used to discover all strong association rules. The support of an itemset is defined as the percentage of the dataset that contains this itemset (Harrington, 2012). The confidence gives the strength of the rules and measures how often an item in Y appears in transactions that contain X (Murthy, Gopalan \& Venkateswarlu, 2018). Lift quantifies the relationship between $X$ and $Y$. A lift value greater than 1 provides strong evidence that $X$ and $Y$ depend on each other (Ordonez, 2006). Practical implications are ruling whose lift value is greater than 1, and support and confidence closer to 1 (Han et al., 2011). Metrics and formulas are given below:

1) Support: $\operatorname{support}(X \Rightarrow Y)=P(X \cup Y)$

2) Confidence: $\operatorname{confidence}(X \Rightarrow Y)=P(X)=\frac{\operatorname{support}(X \cup Y)}{\operatorname{support}(X)}$

3) Lift: $\operatorname{lift}(X, Y)=\frac{P(X \cup Y)}{P(X) P(Y)}$

To provide a clearer presentation of the results, the responses with a support value larger than 0.5 , a confidence value larger than 0.8 , and a lift larger than 1 were included in the analysis. The listing of the rules first referred to the lift value, followed by confidence, and finally support, in the respective descending order.

\section{RESULTS}

\section{What are the children's playing game tendencies?}

The frequency and percentage of cases of time spent playing games were grouped around the way of playing games (ND: Non-Digital Games, PC: Computer Games, SP\&T: Smartphone-Tablet, GC: Game Console), and weekdays-weekends categories. The percentages were calculated according to the rate of the sample for each of these factors. The way of game play by students was analyzed with time spent playing games during weekdays and weekends (Table 1).

Table 1. Time Spent Playing Games on Days of The Weeks, For Way of Game Play

\begin{tabular}{cccccccc}
\hline $\begin{array}{c}\text { Way of } \\
\text { game play }\end{array}$ & $\mathbf{3 0} \mathbf{~ m i n}$ & $\mathbf{1 h}$ & $\mathbf{2 h}$ & $\mathbf{3 h}$ & 4h or more & None & $\begin{array}{c}\text { Don't } \\
\text { know }\end{array}$ \\
\hline \multirow{2}{*}{ ND } & \multicolumn{7}{c}{ Weekdays } \\
& 2107 & 2434 & 1780 & 839 & 728 & 1731 & 520 \\
\cline { 2 - 7 } & $(20.78 \%)$ & $(24.01 \%)$ & $(17.56 \%)$ & $(8.27 \%)$ & $(7.18 \%)$ & $(17.07 \%)$ & $(5.13 \%)$ \\
\hline \multirow{2}{*}{ PC } & 2165 & 1908 & 1025 & 469 & 568 & 3606 & 398 \\
\cline { 2 - 8 } & $(21.35 \%)$ & $(18.82 \%)$ & $(10.11 \%)$ & $(4.63 \%)$ & $(5.60 \%)$ & $(35.57 \%)$ & $(3.92 \%)$ \\
\hline \multirow{2}{*}{ SP\&T } & 2638 & 2507 & 1512 & 784 & 827 & 1514 & 357 \\
\hline \multirow{2}{*}{ GC } & $(26.02 \%)$ & $(24.73 \%)$ & $(14.91 \%)$ & $(7.73 \%)$ & $(8.15 \%)$ & $(14.93 \%)$ & $(3.52 \%)$ \\
\cline { 2 - 7 } & 798 & 565 & 316 & 171 & 235 & 7738 & 316 \\
\hline & $(7.87 \%)$ & $(5.57 \%)$ & $(3.12 \%)$ & $(1.69 \%)$ & $(2.32 \%)$ & $(76.32 \%)$ & $(3.11 \%)$ \\
\hline
\end{tabular}




\begin{tabular}{cccccccc}
\hline \multicolumn{7}{c}{ Weekends } \\
\hline \multirow{2}{*}{ ND } & 1359 & 1960 & 1875 & 1186 & 1836 & 1496 & 427 \\
\cline { 2 - 7 } & $(13.40 \%)$ & $(19.33 \%)$ & $(18.49 \%)$ & $(11.70 \%)$ & $(18.11 \%)$ & $(14.76 \%)$ & $(4.21 \%)$ \\
\hline \multirow{2}{*}{ PC } & 1621 & 1880 & 1474 & 801 & 1307 & 2658 & 398 \\
\cline { 2 - 7 } & $(15.99 \%)$ & $(18.54 \%)$ & $(14.54 \%)$ & $(7.90 \%)$ & $(12.89 \%)$ & $(26.22 \%)$ & $(3.92 \%)$ \\
\hline \multirow{2}{*}{ SP\&T } & 1863 & 2355 & 1873 & 1152 & 1560 & 934 & 402 \\
\cline { 2 - 7 } & $(18.37 \%)$ & $(23.23 \%)$ & $(18.47 \%)$ & $(11.36 \%)$ & $(15.39 \%)$ & $(9.21 \%)$ & $(3.97 \%)$ \\
\hline \multirow{2}{*}{ GC } & 710 & 733 & 459 & 273 & 420 & 7231 & 313 \\
\cline { 2 - 7 } & $(7.00 \%)$ & $(7.23 \%)$ & $(4.53 \%)$ & $(2.69 \%)$ & $(4.14 \%)$ & $(71.32 \%)$ & $(3.09 \%)$ \\
\hline
\end{tabular}

ND: Non-Digital Games, PC: Computer Games, SPET: Smartphone-Tablet, GC: Game Console; min: Minutes, h: $\operatorname{Hour}(s)$

According to Table 1, it is understood that the students usually spend 1 hour (\%24.01) playing non-digital games (like football, hide and seek, etc.) on weekdays, whereas \%17.07 of the students never played such games. A review of the data on digital games reveals that games on PCs, smartphones \& tablets, and game consoles usually took 30 minutes of the day. On the other hand, the students usually spend 1 hour (\%19.33) playing non-digital games on weekends, whereas $\% 14.75$ of the students never played such games. A review of the data on digital games reveals that games on PCs, smartphones \& tablets, and game consoles usually took 1 hour of the day.

Table 2. Time Spent Playing Games on Days of The Weeks, For Way of Game Play, By Gender

\begin{tabular}{|c|c|c|c|c|c|c|c|c|}
\hline $\begin{array}{l}\text { Way of } \\
\text { game } \\
\text { play }\end{array}$ & Gender & $30 \mathrm{~min}$ & $1 \mathrm{~h}$ & $2 \mathrm{~h}$ & $3 \mathrm{~h}$ & $\begin{array}{l}4 \mathrm{~h} \text { or } \\
\text { more }\end{array}$ & None & $\begin{array}{l}\text { Don't } \\
\text { know }\end{array}$ \\
\hline \multicolumn{9}{|c|}{ Weekdays } \\
\hline \multirow{2}{*}{ ND } & Girl & $\begin{array}{c}1163 \\
(26.44 \%)\end{array}$ & $\begin{array}{c}1030 \\
(23.42 \%)\end{array}$ & $\begin{array}{c}573 \\
(13.03 \%) \\
\end{array}$ & $\begin{array}{c}240 \\
(5.46 \%)\end{array}$ & $\begin{array}{c}171 \\
(3.89 \%) \\
\end{array}$ & $\begin{array}{c}1004 \\
(22.83 \%) \\
\end{array}$ & $\begin{array}{c}217 \\
(4.93 \%) \\
\end{array}$ \\
\hline & Boy & $\begin{array}{c}944 \\
(16.44 \%)\end{array}$ & $\begin{array}{c}1404 \\
(24.46 \%)\end{array}$ & $\begin{array}{c}1207 \\
(21.02 \%)\end{array}$ & $\begin{array}{c}599 \\
(10.43 \%)\end{array}$ & $\begin{array}{c}557 \\
(9.7 \%)\end{array}$ & $\begin{array}{c}727 \\
(12.66 \%)\end{array}$ & $\begin{array}{c}303 \\
(5.29 \%)\end{array}$ \\
\hline \multirow{2}{*}{ PC } & Girl & $\begin{array}{c}1186 \\
(26.97 \%)\end{array}$ & $\begin{array}{c}744 \\
(16.91 \%) \\
\end{array}$ & $\begin{array}{c}316 \\
(7.19 \%) \\
\end{array}$ & $\begin{array}{c}113 \\
(2.57 \%)\end{array}$ & $\begin{array}{c}111 \\
(2.52 \%)\end{array}$ & $\begin{array}{c}1772 \\
(40.29 \%)\end{array}$ & $\begin{array}{c}156 \\
(3.55 \%) \\
\end{array}$ \\
\hline & Boy & $\begin{array}{c}979 \\
(17.05 \%) \\
\end{array}$ & $\begin{array}{c}1164 \\
(20.28 \%) \\
\end{array}$ & $\begin{array}{c}709 \\
(12.35 \%) \\
\end{array}$ & $\begin{array}{c}356 \\
(6.20 \%) \\
\end{array}$ & $\begin{array}{c}457 \\
(7.96 \%) \\
\end{array}$ & $\begin{array}{c}1834 \\
(31.95 \%) \\
\end{array}$ & $\begin{array}{c}242 \\
(4.21 \%) \\
\end{array}$ \\
\hline \multirow{2}{*}{ SP\&T } & Girl & $\begin{array}{c}1344 \\
(30.56 \%)\end{array}$ & $\begin{array}{c}1106 \\
(25.15 \%)\end{array}$ & $\begin{array}{c}622 \\
(14.14 \%)\end{array}$ & $\begin{array}{c}298 \\
(6.78 \%) \\
\end{array}$ & $\begin{array}{c}298 \\
(6.78 \%) \\
\end{array}$ & $\begin{array}{c}586 \\
(13.32 \%) \\
\end{array}$ & $\begin{array}{c}144 \\
(3.27 \%) \\
\end{array}$ \\
\hline & Boy & $\begin{array}{c}1294 \\
(22.54 \%)\end{array}$ & $\begin{array}{c}1401 \\
(24.40 \%)\end{array}$ & $\begin{array}{c}890 \\
(15.5 \%)\end{array}$ & $\begin{array}{c}486 \\
(8.47 \%)\end{array}$ & $\begin{array}{c}529 \\
(9.21 \%)\end{array}$ & $\begin{array}{c}928 \\
(16.17 \%)\end{array}$ & $\begin{array}{c}213 \\
(3.71 \%)\end{array}$ \\
\hline \multirow{2}{*}{ GC } & Girl & $\begin{array}{c}277 \\
(6.30 \%)\end{array}$ & $\begin{array}{c}114 \\
(2.59 \%)\end{array}$ & $\begin{array}{c}6 \\
(1.36 \%)\end{array}$ & $\begin{array}{c}32 \\
(0.73 \%)\end{array}$ & $\begin{array}{c}32 \\
(0.73 \%)\end{array}$ & $\begin{array}{c}3769 \\
(85.7 \%)\end{array}$ & $\begin{array}{c}114 \\
(2.59 \%)\end{array}$ \\
\hline & Boy & $\begin{array}{c}521 \\
(9.08 \%)\end{array}$ & $\begin{array}{c}451 \\
(7.86 \%)\end{array}$ & $\begin{array}{c}256 \\
(4.46 \%)\end{array}$ & $\begin{array}{c}139 \\
(2.42 \%)\end{array}$ & $\begin{array}{c}203 \\
(3.53 \%)\end{array}$ & $\begin{array}{c}3969 \\
(69.13 \%)\end{array}$ & $\begin{array}{c}202 \\
(3.52 \%)\end{array}$ \\
\hline
\end{tabular}




\begin{tabular}{|c|c|c|c|c|c|c|c|c|}
\hline & \multicolumn{7}{|c|}{ Weekends } & \multirow[b]{2}{*}{$\begin{array}{c}174 \\
(3.96 \%)\end{array}$} \\
\hline \multirow{2}{*}{ ND } & Girl & $\begin{array}{c}723 \\
(16.44 \%) \\
\end{array}$ & $\begin{array}{c}994 \\
(22.60 \%) \\
\end{array}$ & $\begin{array}{c}760 \\
(17.28 \%) \\
\end{array}$ & $\begin{array}{c}432 \\
(9.82 \%) \\
\end{array}$ & $\begin{array}{c}510 \\
(11.6 \%) \\
\end{array}$ & $\begin{array}{c}805 \\
(18.3 \%) \\
\end{array}$ & \\
\hline & Boy & $\begin{array}{c}636 \\
(11.08 \%) \\
\end{array}$ & $\begin{array}{c}966 \\
(16.82 \%) \\
\end{array}$ & $\begin{array}{c}1,115 \\
(19.42 \%) \\
\end{array}$ & $\begin{array}{c}754 \\
(13.13 \%) \\
\end{array}$ & $\begin{array}{c}1326 \\
(23.1 \%) \\
\end{array}$ & $\begin{array}{c}691 \\
(12.04 \%) \\
\end{array}$ & $\begin{array}{c}253 \\
(4.41 \%) \\
\end{array}$ \\
\hline \multirow{2}{*}{ PC } & Girl & $\begin{array}{c}932 \\
(21.19 \%) \\
\end{array}$ & $\begin{array}{c}871 \\
(19.81 \%) \\
\end{array}$ & $\begin{array}{c}541 \\
(12.30 \%) \\
\end{array}$ & $\begin{array}{c}217 \\
(4.93 \%) \\
\end{array}$ & $\begin{array}{c}246 \\
(5.59 \%) \\
\end{array}$ & $\begin{array}{c}1,432 \\
(32.56 \%) \\
\end{array}$ & $\begin{array}{c}159 \\
(3.62 \%) \\
\end{array}$ \\
\hline & Boy & $\begin{array}{c}689 \\
(12.00 \%) \\
\end{array}$ & $\begin{array}{c}1009 \\
(17.58 \%) \\
\end{array}$ & $\begin{array}{c}933 \\
(16.25 \%) \\
\end{array}$ & $\begin{array}{c}584 \\
(10.17 \%)\end{array}$ & $\begin{array}{c}1,061 \\
(18.48 \%) \\
\end{array}$ & $\begin{array}{c}1,226 \\
(21.36 \%) \\
\end{array}$ & $\begin{array}{c}239 \\
(4.16 \%) \\
\end{array}$ \\
\hline \multirow{2}{*}{ SP\&T } & Girl & $\begin{array}{c}953 \\
(21.67 \%) \\
\end{array}$ & $\begin{array}{c}1071 \\
(24.35 \%) \\
\end{array}$ & $\begin{array}{c}812 \\
(18.46 \%) \\
\end{array}$ & $\begin{array}{c}456 \\
(10.37 \%) \\
\end{array}$ & $\begin{array}{c}569 \\
(12.94 \%) \\
\end{array}$ & $\begin{array}{c}362 \\
(8.23 \%) \\
\end{array}$ & $\begin{array}{c}175 \\
(3.98 \%) \\
\end{array}$ \\
\hline & Boy & $\begin{array}{c}910 \\
(15.85 \%) \\
\end{array}$ & $\begin{array}{c}1284 \\
(22.37 \%)\end{array}$ & $\begin{array}{c}1061 \\
(18.48 \%) \\
\end{array}$ & $\begin{array}{c}696 \\
(12.12 \%) \\
\end{array}$ & $\begin{array}{c}991 \\
(17.26 \%) \\
\end{array}$ & $\begin{array}{c}572 \\
(9.96 \%)\end{array}$ & $\begin{array}{c}227 \\
(3.96 \%) \\
\end{array}$ \\
\hline \multirow{2}{*}{ GC } & Girl & $\begin{array}{c}245 \\
(5.57 \%)\end{array}$ & $\begin{array}{c}191 \\
(4.34 \%)\end{array}$ & $\begin{array}{c}87 \\
(1.98 \%) \\
\end{array}$ & $\begin{array}{c}54 \\
(1.23 \%) \\
\end{array}$ & $\begin{array}{c}51 \\
(1.16 \%) \\
\end{array}$ & $\begin{array}{c}3654 \\
(83.08 \%) \\
\end{array}$ & $\begin{array}{c}116 \\
(2.64 \%) \\
\end{array}$ \\
\hline & Boy & $\begin{array}{c}465 \\
(8.10 \%) \\
\end{array}$ & $\begin{array}{c}542 \\
(9.44 \%) \\
\end{array}$ & $\begin{array}{c}372 \\
(6.48 \%)\end{array}$ & $\begin{array}{c}219 \\
(3.81 \%) \\
\end{array}$ & $\begin{array}{c}369 \\
(6.43 \%) \\
\end{array}$ & $\begin{array}{c}3577 \\
(62.31 \%) \\
\end{array}$ & $\begin{array}{c}197 \\
(3.43 \%) \\
\end{array}$ \\
\hline
\end{tabular}

ND: Non-Digital Games, PC: Computer Games, SPET: Smartphone-Tablet, GC: Game Console; min: Minutes, h: $\operatorname{Hour}(s)$

In terms of gender, the way of game play by students was analyzed with time spent playing games during weekdays and weekends, which is presented in Table 2. On weekdays, girls usually spent 30 minutes (\%26.44) playing non-digital games, whereas the largest group of boys spent 1 hour (\%24.46) with these games. On the other hand, girls usually spent 30 minutes on games on PCs, smartphones \& tablets, and game consoles, whereas boys often spent 1 hour on PC and smartphone \& tablet games, and 30 minutes on console games. On weekends, girls usually spent 1 hour (\%22.6) playing non-digital games, whereas the largest group of boys spent 4 hours (\%23.1) with these games. A review of the data on digital games reveals that games on PCs, smartphones \& tablets, and game consoles respectively took 30 minutes, 1 hour, and 30 minutes of the day for the largest group of girls included in the study. Boys, in turn, spent 4 hours or more on PC games, 1 hour on smartphone \& tablet games, and 1 hour on console games.

\section{What are the children's digital game preferences?}

In the survey, students were asked to choose 62 specific digital game names (for example; Candy Crush, FIFA, PES, Temple Run) and other choices for other games if they played. Each of the digital games the student plays had a different feature. For this reason, these games were examined under five categories: game genre, game language, payment options, online/offline options, game platform.

Based on the games played by the students, eight game genre variables (action, adventure, classic, puzzle, racing, simulation, sports, and strategy) were created. Each of the eight genres can get a value of 0 or more, depending on the number of games played. To understand whether the students play each type of game or not, these eight variables were transformed as new dichotomous variables were created. If the genre value was greater than 0 , it was re-encoded to " 1 ", otherwise " 0 ". None of the students had a value of " 0 " for each genre at the same time. Therefore, the game type of a total of 10139 student data was included in the analysis. The same method was applied for the other game features. Besides, while calculating the rates, total girls' frequency for girls, total boys' frequency for boys, and the total number of students for general were considered. 


\section{Game Genre}

The details regarding the genre of the games played by the students are presented in Figure 1. Action games rank at the top of the list for girls (\%94.7), boys (\%96.6), and general (\%95.6) in terms of genre. While simulation and sports are the least frequently played games for general (\%65.5). A glance at the findings, regarding gender, reveals that girls, sports games (\%41.3) were the least popular genre. Among boys, on the other hand, simulations (\%61.6) were at the bottom.

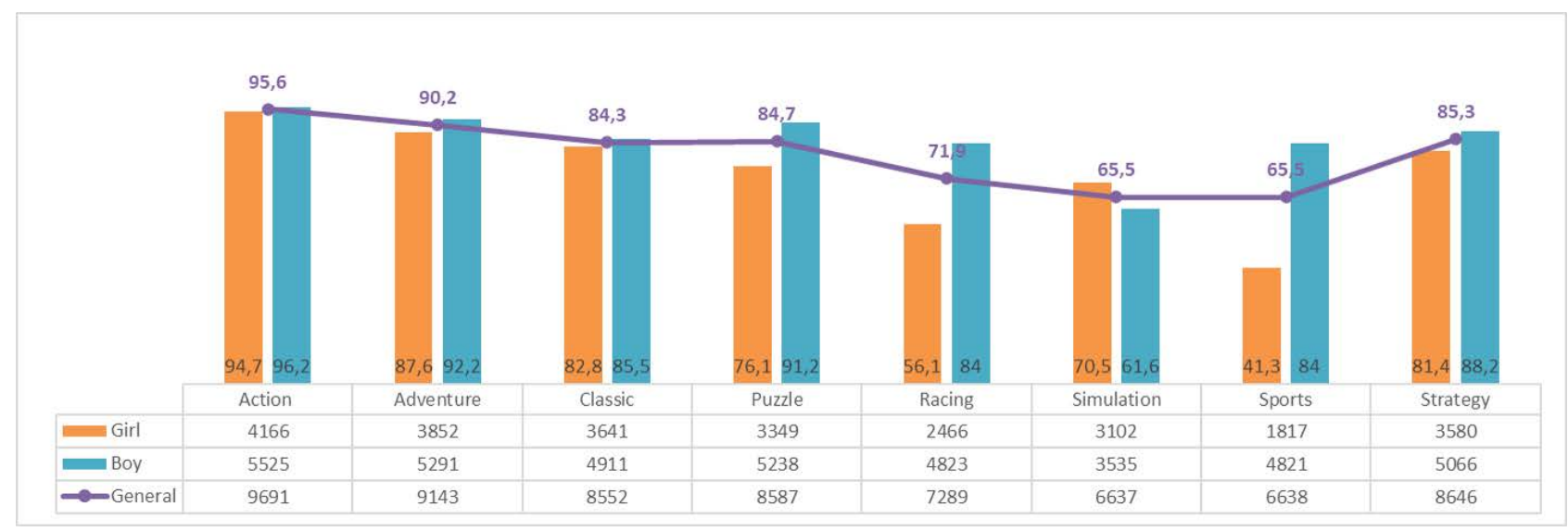

Figure 1. Distribution of the Digital Games Played by The Students, Based on Game Genre

\section{Game Language}

The analysis of the students' game play preferences based on the game language reveals that $\% 99,8$ of the games covered were in the Turkish language, and \%99,2 was in the English language (Figure 2). Almost all the girls and boys (except for only 1 boy) play games in both English and Turkish. This rate is at least $\% 99$ for each group.

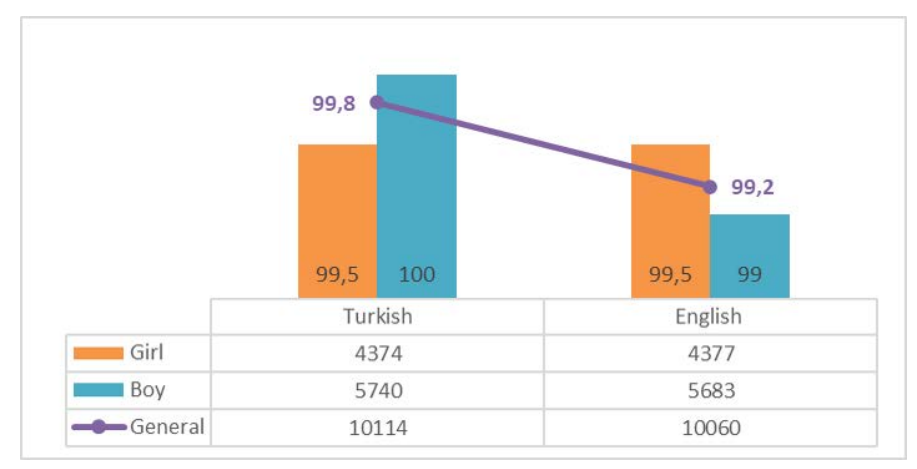

Figure 2. Distribution of the Digital Games Played by The Students, Based on Game Language

\section{Payment Options}

The payment options preferences of the games played by the students, by gender, are summarized in Figure 3. A glance at the payment options of the games played by the students reveals that almost all students (except for only 1 girl) were involved in in-app purchases. Second, free games $(\% 95,5)$ and paid games $(\% 67)$ take the last place. Similar results were found in terms of gender. Paid games are the least common preference for girls $(\% 37,5)$, while for boys $(\% 89,7)$. 


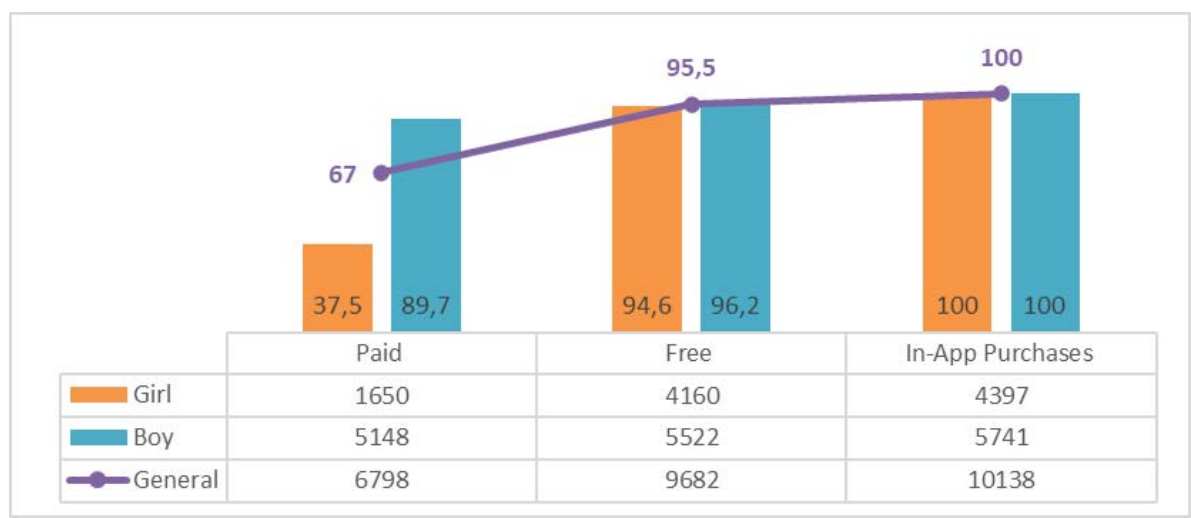

Figure 3. Distribution of the Digital Games Played by The Students, Based on Payment Options

\section{Online/Offline Options}

The online/offline options preferences of the games played by the students, by gender, are summarized in Figure 4. It is seen that almost all students (except only 1 boy) play online games. Second, both online and offline playable games $(\% 92,7)$ and offline games $(\% 22,3)$ take the last place. Similar results were found in terms of gender. Offline games are the least common for girls $(\% 5,5)$ and boys $(\% 35,2)$, and boys' rate is more than for girls' rate.

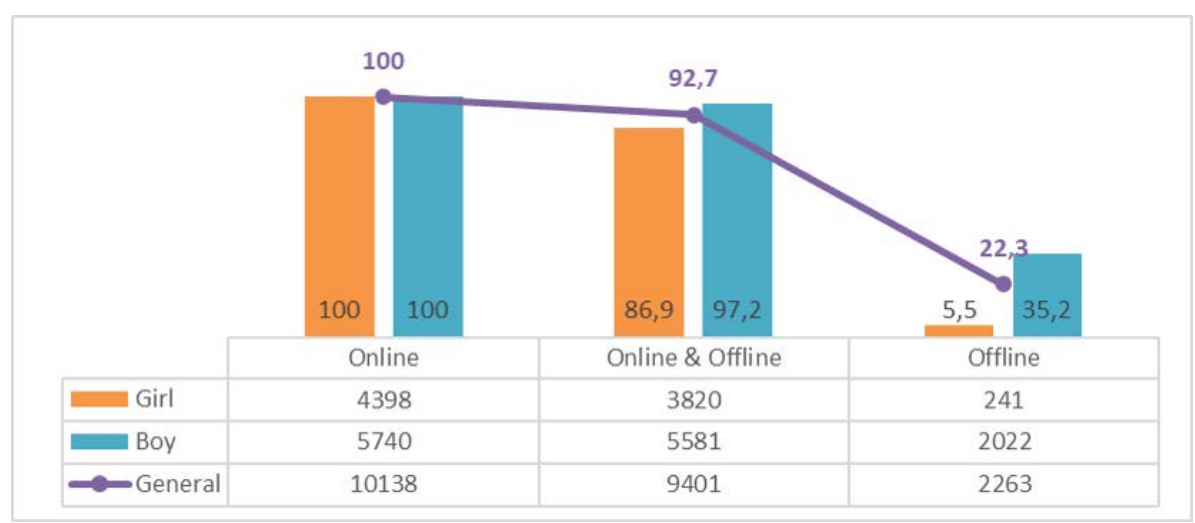

Figure 4. Distribution of the Digital Games Played by The Students, Based on Online/Offline Options

\section{Game Platform}

The game platforms of the games played by the students are summarized in Figure 5. Findings reveal that almost all students (except for only 2 boys) play mobile platforms games. Generally, it was found that the least preferred gaming platform is the computer $(\% 22,3)$. On the other hand, in terms of gender, games that can be played on both pc, mobile, and console devices were the least preferred game platform for girls (\%10) and boys $(\% 36,3)$. Girls $(\% 91,7)$ preferred games played on both computer and mobile devices more than boys (\%80,5). In other categories, boys prefer them more than girls. 


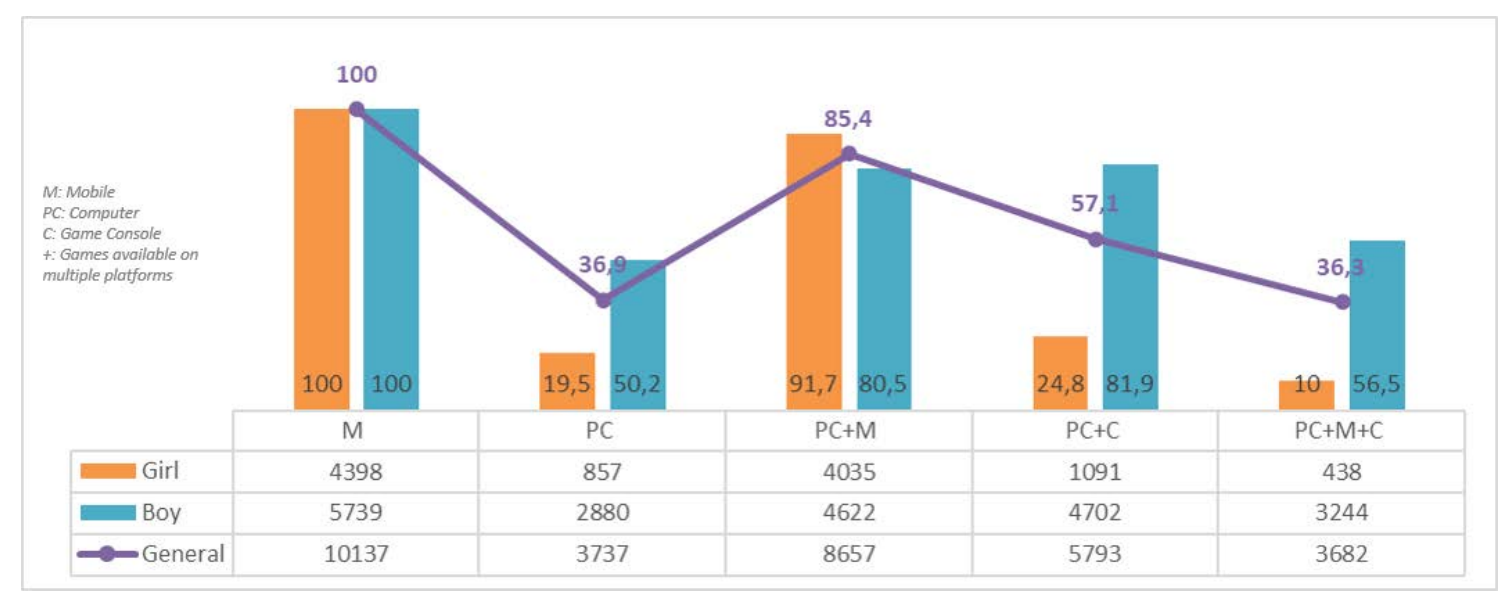

Figure 5. Distribution of the Digital Games Played by The Students, Based on Game Platform

\section{Which digital games are popular and played together among the children?}

These findings present the frequency of the games played by the students, and their possible association rules, for all students and as by gender preferences.

\section{Most Played Games}

Table 3 presents the data ranked in descending order. The support value reflects the frequency of the item sets among all games. Length, on the other hand, specifies the number of games available in each item set. In this context, Minecraft stands out as the most frequently played game, by being present in \%70 of the item sets for all students. The item set comprised a two-game combination, namely Temple Run and Subway Surfers, on the other hand, ranks 7th among all games, in terms of playing frequency.

Table 3. Most Frequently Played Digital Games

\begin{tabular}{cccc}
\hline Rank & Support & Item Sets & Length \\
1 & 0.70 & MINECRAFT & 1 \\
2 & 0.67 & SUBWAYSURFERS & 1 \\
3 & 0.64 & HAYDAY & 1 \\
4 & 0.63 & ATESVESU & 1 \\
5 & 0.62 & KELIMELIK & 1 \\
6 & 0.62 & TEMPLERUN & 1 \\
7 & 0.55 & TEMPLERUN, SUBWAYSURFERS & 2 \\
8 & 0.54 & CLASHROYALE & 1 \\
9 & 0.53 & AGAR & 1 \\
10 & 0.52 & COUNTERSTRIKE & 1 \\
\hline
\end{tabular}

A glance at Table 4 reveals that Subway Surfers is included in \%79 of the item sets containing the games played by girls included in the sample, making it the most frequently played game for this gender. The most frequently played two-game combination for girls, on the other hand, is Temple Run and Subway Surfers, which is included in \%66 of all item sets for girls. 
AJER - Academia Eğitim Araştırmaları Dergisi 2022, 7(1), 7-23

https://dergipark.org.tr/pub/egitim e-ISSN 2619-9351

Table 4. Most Frequently Played Digital Games for Girls

\begin{tabular}{cccc}
\hline Rank & Support & Item Sets & Length \\
1 & 0.79 & SUBWAYSURFERS & 1 \\
2 & 0.78 & ATESVESU & 1 \\
3 & 0.73 & TEMPLERUN & 1 \\
4 & 0.67 & AA & 1 \\
5 & 0.66 & TEMPLERUN, SUBWAYSURFERS & 2 \\
6 & 0.64 & ATESVESU, SUBWAYSURFERS & 2 \\
7 & 0.61 & TOM & 1 \\
8 & 0.60 & ATESVESU, TEMPLERUN & 2 \\
9 & 0.60 & MINECRAFT & 1 \\
10 & 0.56 & CLASHOFCLANS & 1 \\
\hline
\end{tabular}

A glance at Table 5 reveals that Hay Day is included in \%81 of the item sets containing the games played by boys included in the sample, making it the most frequently played game for this gender. The most frequently played 2-game combination for boys, on the other hand, is Minecraft and Hay Day, which is included in \%65 of all item sets for girls.

Table 5. Most Frequently Played Digital Games for Boys

\begin{tabular}{cccc}
\hline Rank & Support & Item Sets & Length \\
1 & 0.81 & HAYDAY & 1 \\
2 & 0.76 & MINECRAFT & 1 \\
3 & 0.72 & KELIMELIK & 1 \\
4 & 0.71 & CLASHROYALE & 1 \\
5 & 0.70 & COUNTERSTRIKE & 1 \\
6 & 0.66 & PIANOTILES & 1 \\
7 & 0.65 & CRIMINALCASE & 1 \\
8 & 0.65 & MINECRAFT, HAYDAY & 2 \\
9 & 0.63 & OTHER & 1 \\
10 & 0.61 & KELIMELIK, HAYDAY & 2 \\
\hline
\end{tabular}

\section{Most Played Games Together}

The analysis of Table 6 leads to two essentially similar rules, based on the criteria established. Looking at rule 1, one would find that the probability of Subway Surfers players playing Temple Run as well is \%89 (confidence), given the fact that the two games are included in combination in approximate \%54 (support) of all item sets. Finally, the students who play Subway Surfers are 1.32 times (lift) more likely to play Temple Run as well. A glance at rule 2 reveals that it is not much different than rule 1. The most significant difference between the two is that Temple Run players also play Subway Surfers, with the probability of combination being \%89, while the likelihood of Subway Surfers players also playing Temple Run is \%81.

Table 6. Association Rules

\begin{tabular}{llccc}
\hline \multicolumn{2}{l}{ Rule } & Support & Confidence & Lift \\
1 & SUBWAYSURFERS $\Rightarrow$ TEMPLERUN & 0.5477 & 0.8881 & 1.3160 \\
2 & TEMPLERUN $\Rightarrow$ SUBWAYSURFERS & 0.5477 & 0.8115 & 1.3160 \\
\hline
\end{tabular}

The combination rules applicable to girls are presented in Table 7, while those applicable to boys are presented in Table 8 . Both tables present the top 10 rules ranked by the criteria specified. 
Table 7. Association Rules for Girls

\begin{tabular}{llccc}
\hline Rule & Support & Confidence & Lift \\
1 & TEMPLERUN $\Rightarrow$ SUBWAYSURFERS & 0.5471 & 0.8598 & 1.1733 \\
2 & SUBWAYSURFERS $\Rightarrow$ TEMPLERUN & 0.5471 & 0.9108 & 1.1510 \\
3 & ATESVESU $\Rightarrow$ SUBWAYSURFERS & 0.6644 & 0.9067 & 1.1458 \\
4 & SUBWAYSURFERS $\Rightarrow$ ATESVESU & 0.6644 & 0.8396 & 1.1458 \\
5 & TEMPLERUN $\Rightarrow$ ATESVESU & 0.5206 & 0.8484 & 1.0935 \\
6 & AA $\Rightarrow$ SUBWAYSURFERS & 0.5471 & 0.8233 & 1.0613 \\
7 & $\{$ ATESVESU, TEMPLERUN\} $\Rightarrow$ SUBWAYSURFERS & 0.5146 & 0.8386 & 1.0597 \\
8 & $\{$ ATESVESU, SUBWAYSURFERS\} $\Rightarrow$ TEMPLERUN & 0.6006 & 0.8196 & 1.0565 \\
9 & $\{$ TEMPLERUN, SUBWAYSURFERS\} $\Rightarrow$ ATESVESU & 0.5562 & 0.8358 & 1.0562 \\
10 & TOM $\Rightarrow$ ATESVESU & 0.6362 & 0.8201 & 1.0363 \\
\hline
\end{tabular}

In the light of the rules presented in Table 7, one can argue that, among girls, the playing of Temple Run increases the likelihood of playing Subway Surfer as well, by a factor of approximately 1.17.

Table 8. Association Rules for Boys

\begin{tabular}{llccc}
\hline Rule & & Support & Confidence & Lift \\
1 & FIFA $\Rightarrow$ PIANOTILES & 0.5087 & 0.8326 & 1.2584 \\
2 & $\{$ MINECRAFT, COUNTERSTRIKE $\} \Rightarrow$ CLASHROYALE & 0.5014 & 0.8669 & 1.2239 \\
3 & $\{$ MINECRAFT, CLASHROYALE $\Rightarrow$ COUNTERSTRIKE & 0.5014 & 0.8556 & 1.2155 \\
4 & CLASHROYALE $\Rightarrow$ COUNTERSTRIKE & 0.5885 & 0.8361 & 1.1804 \\
5 & COUNTERSTRIKE $\Rightarrow$ CLASHROYALE & 0.5885 & 0.8309 & 1.1804 \\
6 & SUBWAYSURFERS $\Rightarrow$ KELIMELIK & 0.5062 & 0.8453 & 1.1692 \\
7 & $\{$ CLASHROYALE, HAYDAY\} $\Rightarrow$ MINECRAFT & 0.5076 & 0.8542 & 1.1195 \\
8 & $\{$ COUNTERSTRIKE, CLASHROYALE\} $\Rightarrow$ MINECRAFT & 0.5014 & 0.8520 & 1.1166 \\
9 & PIANOTILES $\Rightarrow$ HAYDAY & 0.5908 & 0.8930 & 1.1067 \\
10 & $\{$ KELIMELIK, HAYDAY $\Rightarrow$ MINECRAFT & 0.5189 & 0.8437 & 1.1058 \\
\hline
\end{tabular}

In the light of the rules presented in Table 8, one can argue that, among boys, the playing of FIFA increases the likelihood of playing Piano Tiles as well, by a factor of approximately 1.26.

\section{DISCUSSION AND CONCLUSION}

Developments in science and technology have changed the concept of the game, which has a cultural structure, as in many other fields. These changes led to the replacement of games that had hitherto been played face-to-face and often outdoors, with digital games. The development in information and communication technologies has made digital games designed for entertainment a market, and this process has turned into an exciting adventure for digital game enthusiasts. The increase in computer ownership and data storage capabilities, not to mention internet connection speeds, coupled with the diversity of portable devices and the growth of social media, were all factors which helped further the development of the digital games industry. The spread of mobile devices, on the other hand, facilitated access to digital games anytime and anywhere. Therefore, it can be said that digital games are popular with today's children and teenagers, who are called digital natives. At this junction, the definition and features of digital games, and the reasons shaping preferences about them are considered important topics of research. In this study, playing game tendencies and digital game preferences of 4th-8th grade students were determined and its 
distribution according to gender was examined.

Within the scope of the first research question focusing on children's playing game tendencies, the time spent playing games on days of the weeks was examined according to the way game play, in terms of gender. According to this, on weekdays, girls usually spent 30 minutes on non-digital games, while boys spent 1 hour. Girls usually spent 30 minutes on computer games, smartphone \& tablet games, and with game consoles, whereas the largest number of boys spent 1 hour on computer games and smartphone \& tablet games, and 30 minutes on game consoles. On the other hand, on weekends, the girls were found to usually spend 1 hour on non-digital games, while boys spent 4 hours or more. Again, on weekends, girls spent 30 minutes, 1 hour, and 30 minutes respectively on computer games, smartphones \& tablet games, and game consoles, while the respective numbers for boys were 4 hours or more, 1 hour, and again, 1 hour. These findings suggest that, compared to girls, boys spend more time on games, and children spent even more time on weekends. Similarly, in the literature, it is concluded that boys generally play more games than girls (Taştekin, 2019; Männikkö et al., 2018; Hastings et al., 2009) and that there is an increase in the average in time spent playing games of students on weekends (Oflu \& Yalçın, 2019).

In the second research question focusing on children's digital game preferences, the games played by the students were examined under five features: game genre, game language, payment options, online/offline options, and game platform. In terms of game genre, action games stand out as the most popular genre among the students, while simulations and sports games were found to be the least popular. On the other hand, sports games were less preferred among girls and simulation games among boys. Action games again rank at the top of the list of popular genres for each gender. Findings regarding the most played game genre in the literature differ as adventure/action (Oflu \& Yalçın, 2019; Taylan \& Durğun, 2017; Thorne et al., 2014), strategy/tactical (Phan, 2011), competition (Topal \& Aydin). It is thought that this situation arises from the different classifications of the games, the diversification of popular games in terms of genres, and the changes in individuals' game preferences. As a matter of fact, Quaiser-Pohl et al. (2006) also concluded in the study that boys prefer action games more, and they predicted that the difference between boys and girls may close due to the development of technology over time.

When other features are examined, in terms of game language, both Turkish and English language games are preferred almost equally. Therefore, it can be said that the game language does not affect game preferences. However, it was determined that while girls preferred Turkish games more with a rate of approximately \%56, boys preferred English games more at the same rate. This may be since boys are more motivated to play games (Veltri et al., 2014). In terms of payment options, the games offering in-app purchases were found to be popular choices. Although paid games are the least preferred, this ratio is much lower for girls than boys. In terms of online/offline options, it was found that both girls and boys prefer online games the most, while offline games were almost never preferred. In the same vein, Taylan et al. (2017) found that more than half of the students involved in the study preferred online games. This finding can be interpreted as online games precede offline games due to easier access to the internet. In terms of game platform, it was concluded that the students mostly preferred the games that can be available on mobile devices. Indeed, the literature also concurs that computers and smartphones are the most popular gaming platforms (Çavuş, Ayhan \& Tuncer, 2016; Kabali et al., 2015; Taylan et al., 2017).

In the last research question, the digital games that children play the most and together were examined. Among the digital games preferred by the students, the most frequently played game was found to be Minecraft, followed by Subway Surfers as the second most popular game, and Hay 
Day as the third. Girls were found to prefer Subway Surfers, while boys played Hay Day more. When these three games are examined in terms of their features, it is seen that Minecraft and Subway Surfers are in the action game genre, while Hay Day is in the classic. In addition, all three games have the features of in-app purchase, online play, and are available on mobile devices. This indicates that it is consistent with the findings obtained from the second research question. In addition to these, the analysis of frequent pattern mining revealed that \%89 of Temple Run players also played Subway Surfers, whereas \%81 of Subway Surfers players also played Temple Run. Among girls, playing Temple Run led to an increased probability of playing Subway Surfers as well, by a factor of approximately 1.17, whereas among boys, playing FIFA increased the likelihood of playing Piano Tiles as well, by a factor of approximately 1.26 .

The fact that the digital game industry has grown significantly, the number of people playing these games is increasing day by day, and especially the evolution of digital games into an industry such as e-sports has made digital games the focus of research. In a nutshell, the data obtained from the study not only reveal the current situation regarding the digital games played by children but also offer inferences regarding their gender-based preferences. Therefore, as a constantly developing and changing field, it is thought that the indicators obtained from descriptive studies like this study on digital games will be a reference for researchers to see the whole and will guide game developers in terms of preferred features.

\section{REFERENCES}

And, M. (2003). Oyun ve bügü. Türk kültüründe oyun kavramı [Game and magic. Game concept in Turkish culture]. İstanbul: Yapı Kredi Publ.

Caillois, R. (1961). Man, play and games. Barash, M. (Trans.). Chicago: University of Illinois Press.

Colman, A. M. (2016). Game theory and experimental games: The study of strategic interaction. Oxford: Pergamon Press.

Crawford, C. (1984). The art of computer game design. Retrieved from, http://www.worldcolleges.info/sites/default/files/The_Art_of_Computer_Game_Design__Chris_Crawford.pdf

Çavuş, S., Ayhan, B., \& Tuncer, M. (2016). Bilgisayar oyunları ve bağımlılık: Üniversite öğrencileri üzerine bir alan araştırması [Computer games and addiction: A field study on university students]. Illetişim Kuram ve Araştırma Dergisi [Journal of Communication Theory and Research], 43, 265-289.

Çetin, E. (2013). Tanımlar ve temel kavramlar [Definitions and basic concepts]. In M. A. Ocak (Ed.), Eğitsel dijital oyunlar: Kuram, tasarım ve uygulama [Educational digital games: Theory, design and implementation] (pp. 2-18). Ankara: Pegem Akademi.

de Leeuw, J. R. J., de Bruijn, M., de Weert-van Oene, G. H., \& Schrijvers, A. J. (2010). Internet and game behaviour at a secondary school and a newly developed health promotion programme: A prospective study. BMC Public Health, 10(1), 1-8.

Doğu, B. (2006). Popüler kültürün tüketim aracı olarak bilgisayar oyunlarında sunulan yaşam tarzı [Lifestyle represented in computer games as popular culture's medium of consumption] (Unpublished master's thesis). Ege University, İzmir.

Eni, B. (2017). Lise öğrencilerinin dijital oyun bağımlılı̆̆ı ve algıladıkları ebeveyn tutumlarının değerlendirilmesi [Evaluation of digital game addiction and response of high school students] (Unpublished master's thesis). Haliç University, İstanbul.

Griffiths, M. D., \& Hunt, N. (1995). Computer game playing in adolescence: Prevalence and 
demographic indicators. Journal of Community \& Applied Social Psychology, 5(3), 189-193.

Han, J., Kamber, M., \& Pei, J. (2011). Data mining concepts and techniques (3th ed.). Waltham: Elsevier. Harrington, P. (2012). Machine learning in action. New York: Manning Publications.

Hastings, E. C., Karas, T. L., Winsler, A., Way, E., Madigan, A., \& Tyler, S. (2009). Young children's video/computer game use: Relations with school performance and behavior. Issues in Mental Health Nursing, 30(10), 638-649.

Hawi, N. S., Samaha, M., \& Griffiths, M. D. (2019). The digital addiction scale for children: Development and validation. Cyberpsychology, Behavior, and Social Networking, 22(12), 771-778.

Horzum, M. B. (2011). Examining computer game addiction level of primary school students in terms of different variables. Education and Science, 36(159), 56-68.

Horzum, M. B., Ayas, T., \& Balta, Ö. Ç. (2008). Computer game addiction scale for children. Turkish Psychological Counseling and Guidance Journal, 3(30), 76-88.

Huizinga, J. (1955). Homo ludens: A study of the play element in culture. Boston: Beacon Press.

İnal, Y., \& Çağıltay, K. (2005, May). İlköğretim öğrencilerinin bilgisayar oyunu oynama alışkanlıkları ve oyun tercihlerini etkileyen faktörler [The computer game playing habits of primary school students and the factors affecting their game preferences]. Eğitimde Yeni Yönelimler II - Eğitimde Oyun Sempozyumu [New Trends in Education II - Game in Education Symposium], Ankara.

Jia, K. L. (2009, November). Research of word sense disambiguation based on mining association rule. Third International Symposium on Intelligent Information Technology Application Workshops, Nanchang.

Kabali, H. K., Irigoyen, M. M., Nunez-Davis, R., Budacki, J. G., Mohanty, S. H., Leister, K. P., \& Bonner, R. L. (2015). Exposure and use of mobile media devices by young children. Pediatrics, 136(6), 1044-1050.

Kinzie, M. B., \& Joseph, D. R. D. (2008). Gender differences in game activity preferences of middle school children: Implications for educational game design. Educational Technology Research $\mathcal{E}$ Development, 56(5), 643-663.

Kirriemuir, J. (2002). Video gaming, education and digital learning technologies. D-lib Magazine, $8(2)$.

Kukul, V. (2013). Oyunla ilgili tarihsel gelişim ve yaklaşımlar [Historical development and approaches about the game]. In M. A. Ocak (Ed), Eğitsel dijital oyunlar: Kuram, tasarım ve uygulama [Educational digital games: Theory, design and implementation] (pp. 20-31). Ankara: Pegem Akademi.

Lenhart, A., Smith, A., Anderson, M., Duggan, M., \& Perrin, A. (2015). Teens, technology and friendships. Retrieved from, https://apo.org.au/node/56457.

Männikkö, N., Ruotsalainen, H., Demetrovics, Z., Lopez-Fernandez, O., Myllymäki, L., Miettunen, J., \& Kääriäinen, M. (2018). Problematic gaming behavior among Finnish junior high school students: Relation to socio-demographics and gaming behavior characteristics. Behavioral Medicine, 44(4), 324-334.

McMillan, J., \& Schumacher, S. (2010). Research in education: Evidence-based inquiry (7th ed.). London: Pearson Education.

Murthy, T. S., Gopalan, N. P., \& Venkateswarlu, Y. (2018). An efficient method for hiding association rules with additional parameter metrics. International Journal of Pure and Applied Mathematics, 118(7), 285-290.

Oflu, A., \& Yalçın, S. S. (2019). Video game use among secondary school students and associated factors. Arch Argent Pediatr, 117(6), 584-591.

Ordonez, C. (2006). Association rule discovery with the train and test approach for heart disease 
prediction. IEEE Transactions on Information Technology in Biomedicine, 10(2), 334-343.

Phan, M. H. (2011). Video gaming trends: Violent, action/adventure games are most popular. Usability News, 13(2).

Phan, M. H., Jardina, J. R., \& Hoyle, W. S. (2012). Video games: Males prefer violence while females prefer social. Usability News, 14(1).

Quaiser-Pohl, C., Geiser, C., \& Lehmann, W. (2006). The relationship between computer-game preference, gender, and mental-rotation ability. Personality and Individual Differences, 40(3), 609-619.

Sezgin, S. (2016, May). Eğitimde oyunlaştırma üzerine sistematik bir bakış [A systematic view on gamification in education]. VIII. International Congress of Educational Research, Çanakkale.

Sutton-Smith, B. (2004a). Cultivating courage through play. Voices, 30(1/2), 25-28.

Sutton-Smith, B. (2004b). The ambiguity of play: Rhetorics of fate. In H. Bial and S. Brady (Eds.), The performance studies reader (pp. 132-138). New York: Routledge.

Taştekin, E. (2019). Ortaokul öğrencilerinin dijital oyun oynama alışkanlıklarının öğrenci ve veli bakış açısindan incelenmesi [Review of the secondary school students' digital game playing habits from both students and parents perspectives] (Unpublished master's thesis). Balıkesir University, Balıkesir.

Taylan, H. H., Kara, H. Z., \& Durğun, A. (2017). A study on computer game habits and game preferences of secondary and high school students. PESA International Journal of Social Studies, 3(1), 78-87.

Thorne, H. T., Smith, J. J., Morgan, P. J., Babic, M. J., \& Lubans, D. R. (2014). Video game genre preference, physical activity and screen-time in adolescent boys from low-income communities. Journal of Adolescence, 37(8), 1345-1352.

Torun, F., Akçay, A., \& Çoklar, A. N. (2015). Analyzing of computer games effects on social life and academic behaviour of the secondary school students. Karaelmas Journal of Educational Sciences, 3(1), 1-11.

Tüzün, H. (2004). Motivating learners in educational computer games (Unpublished doctoral dissertation). Indiana University, Bloomington.

Uluyol, Ç., Demiralay, R., Şahin, S., \& Eryılmaz, S. (2014). The review of gaming preferences and habits of teacher candidates': Gazi University case. Journal of Instructional Technologies $\mathcal{E}$ Teacher Education, 3(2), 1-7.

Veltri, N., Krasnova, H., Baumann, A., \& Kalayamthanam N. (2014, August). Gender differences in online gaming: A literature review. 20th Americas Conference on Information Systems, Savannah.

Wan, C. S., \& Chiou, W. B. (2006). Why are adolescents addicted to online gaming? An interview study in Taiwan. Cyberpsychology \& Behavior. 9(6), 762-766.

Yang, Y. T. C. (2012). Building virtual cities, inspiring intelligent citizens: Digital games for developing students' problem solving and learning motivation. Computers \& Education, 59(2), 365-377.

Yee, N. (2006). The demographics, motivations and derived experiences of users of massivelymultiuser online graphical environments. Presence: Teleoperators and Virtual Environments, 15(3), 309-329.

Yiğit, E. (2017). Çocukların dijital oyun bă̆̆ılılı̆̆ında ailelerin bazı değişkenler açısından incelenmesi [The investigation of families in children's digital game addiction in terms of some variables] (Unpublished master's thesis). Yüzüncü Yll University, Van. 
In the writing process of the study titled "Examination of Children's Playing Game Tendencies and Digital Game Preferences Based on Gender", the rules of scientific, ethical and citation were followed; it was undertaken by the authors of this study that no falsification was made on the collected data. "Academia Journal of Educational Researchand Editor" had no responsibility for all ethical violations to be encountered, and all responsibility belongs to the authors and that the study was not submitted for evaluation to any other academic publishing environment. 